\title{
Sources of low-arsenic groundwater in the Bengal Basin: investigating the influence of the last glacial maximum palaeosol using a 115-km traverse across Bangladesh
}

\author{
M. A. Hoque • J. M. McArthur • P. K. Sikdar
}

\begin{abstract}
Pollution of groundwater in the Bengal Basin (Bangladesh and West Bengal, India) by arsenic (As) puts at risk the health of more than 100 million consumers. Using 1,580 borehole lithological logs and published hydrochemistry on 2,387 wells, it was predicted that lowAs $(<10 \mu \mathrm{g} / \mathrm{L})$ groundwater exists, in palaeo-interfluvial aquifers of brown sand capped by a protective palaeosol, beneath at least $45,000 \mathrm{~km}^{2}$ of the Bengal Basin. The aquifers were predicted to be at a depth of as little as $25 \mathrm{~m}$ below ground level (mbgl), and typically no more than $50 \mathrm{mbgl}$. The predictions were confirmed along an eastwest traverse $115 \mathrm{~km}$ in length (i.e. across half of Bangladesh) by drilling 28 new boreholes to $91-\mathrm{m}$ depth to reveal subsurface sedimentology, and by mapping As distribution in groundwater. The aquifers identified occur at typically $<40 \mathrm{mbgl}$ and so are accessible with local drilling methods. A protective palaeosol that caps the palaeo-interfluvial aquifers prevents downward movement into them of As-polluted groundwater present in shallower
\end{abstract}

Received: 2 August 2013 / Accepted: 3 April 2014

Published online: 28 May 2014

\section{(C) Springer-Verlag Berlin Heidelberg 2014}

Electronic supplementary material The online version of this article (doi:10.1007/s10040-014-1139-8) contains supplementary material, which is available to authorized users.

\section{A. Hoque $(\varpi) \cdot$ J. M. McArthur}

Earth Sciences,

University College London, Gower Street, London, WC1E 6BT,

UK

e-mail: m.hoque@imperial.ac.uk

Tel.: +44-20-75946074

\section{P. K. Sikdar}

Environment Management,

Indian Institute of Social Welfare and Business Management, College Square, Kolkata, 700073, India

Present Address:

M. A. Hoque

Department of Civil and Environmental Engineering, Imperial College London, South Kensington Campus, London, SW7 2AZ, UK palaeo-channel aquifers and ensures that the palaeointerfluvial aquifers will yield low-As groundwater for the foreseeable future. Their use, in place of the shallower As-polluted palaeo-channel aquifers, would rapidly mitigate the health risks from consumption of As-polluted groundwater.

Keywords Arsenic . Contamination · Bangladesh .

Palaeo-interfluve $\cdot$ Palaeo-channel

\section{Introduction}

In Bangladesh and West Bengal (India), i.e. the Bengal Basin, at least $85 \%$ of the combined populations of 240 million use groundwater for domestic water supply, including for drinking. The groundwater is widely polluted with arsenic (PHED 1991; DPHE 1999, 2001; van Geen et al. 2003b; Jakariya et al. 2007; Nickson et al. 2007; Fendorf et al. 2010), the long-term consumption of which degrades human health (Dhar et al. 1997; Smith et al. 2000; Argos et al. 2010). Mitigation strategies include rainwater harvesting, use of treated surface-water supplies, and exploitation of deep aquifers $(>150 \mathrm{~m}$ below ground level (mbgl) and mostly $>300 \mathrm{mbgl}$ ) which typically contain much less than $10 \mu \mathrm{g} / \mathrm{L}$ of As (DPHE 1999, 2001; Ahmed et al. 2006; van Geen et al. 2007; Ravenscroft et al. 2009). These strategies require capital investment and maintenance that is beyond the capacity of most of the population, given that $90 \%$ of it lives in a rural environment sustained by subsistence farming.

Cheaper mitigation can be obtained by emplacing well screens in aquifers of brown sand, where they are found in the subsurface, typically at depths between 25 and 70 mbgl. Recognised as distinct aquifers by Davies and Exley (1992) and Davies (1995), the brown sand's connection to low-As groundwater was established by P. Ravenscroft of the Department of Public Health Engineering (DPHE) of Government of Bangladesh (DPHE 1999), and confirmed by others (DPHE 2001; van Geen et al. 2003a; McArthur et al. 2004; von Brömssen et al. 2007). Such aquifers contain groundwater in which concentrations of As are $<5 \mu \mathrm{g} / \mathrm{L}$ and not uncommonly $<1 \mu \mathrm{g} / \mathrm{L}$. Other work by Goodbred and 
Kuehl $(1999,2000)$ suggested that the presence of such brown sands, as part of their 'oxidised facies', may be widespread across the Bengal Basin, although those authors did not link them to low-As groundwater. With hindsight, the development of the Bengal Basin outlined by Umitsu (1993) also allows the inference to be drawn that palaeo-interfluves are widespread across the basin and so, by further inference, are brown-sand aquifers.

Mitigation by exploiting aquifers of brown sand is an approach that is at risk from migration downward of Aspolluted groundwater in overlying aquifers. The risk is removed where the brown-sand aquifers are protected from downward recharge by a capping red-clay palaeosol, first noted in central Bangladesh (Davies 1995), that formed much of the land surface (i.e. palaeo-interfluves) during the last glacial maximum (Goodbred and Kuehl 1999, 2000; McArthur et al. 2004, 2008). The combination of capping palaeosol over brown sand is seen most prominently as the upstanding Madhupur and Barind Tracts. The subcrop of this palaeosol represents the buried palaeo-interfluvial regions of the Bengal Basin. If truly widespread and not subsequently removed by erosion, those palaeo-interfluves, now known to host brown-sand aquifers, would constitute a substantial source of low-As groundwater that could be used to mitigate As-pollution in the Bengal Basin. Such a strategy might be applicable to other low-latitude deltas where groundwater is exploited for human consumption, e.g. the aquifers of the Indus (Pakistan), Red and Mekong (Vietnam), Pearl and Yangtze (China) river deltas.

Given the potential importance of these palaeo-interfluvial aquifers (brown sand capped by a palaeosol) to the provision of low-As water across Asian deltas, it is important that their distribution be documented, and their true value as sources of low-As water is assessed. A start to such explicit mapping and assessment has been made in the Bengal Basin by McArthur et al. (2008, 2011, 2012) and Hoque et al. (2012), who document areas of palaeointerfluvial aquifer across parts of West Bengal.

The work reported here has extended that mapping across a large part of Bangladesh by using a combination of groundwater composition and historic drilling $\operatorname{logs}$ to distinguish, in the subsurface, between aquifers in palaeo-channel (PC) settings that host As-polluted groundwater, and aquifers in palaeo-interfluvial (PI) settings that host low-As groundwater. These methods suggested that largely unexploited PI aquifers yielding low-As groundwater exist beneath about one third of Bangladesh and also suggested that they are common in areas where presently almost all groundwater exploitation is from shallower, As-polluted, PC aquifers. Those suggestions were tested by drilling 28 new boreholes along a $115-\mathrm{km}$ traverse across Bangladesh, by doing further analysis for chemical proxies in groundwater of $\mathrm{PI} / \mathrm{PC}$ settings, and by undertaking a new colour survey of wells (McArthur et al. 2011) that enables $\mathrm{PI} / \mathrm{PC}$ settings to be distinguished in the subsurface without drilling or chemical analysis of groundwater.

Hydrogeology Journal (2014) 22: 1535-1547

\section{Study area and its sedimentological development}

The study area is shown in Fig. 1 and comprises much of southern and central Bangladesh. The exploration traverse (Fig. 1) extends due east from the border between Bangladesh and India and has its eastern end within $20 \mathrm{~km}$ of the Ganges (locally termed Padma) River. This traverse crosses much of the As-polluted region of Bangladesh.

The climate of the region is monsoonal, and delivers between 1.5 and $3 \mathrm{~m}$ of rain per year, with the amount increasing from SW to NE. The rain occurs mainly between May and October (Sengupta and Sarkar 2006). The water table is typically only a few metres below ground level but deepens a few metres during the dry season (November-April) in response to natural drainage to rivers and abstraction for domestic use and irrigation. The water level locally may go temporarily below the level at which it can be raised by the suction pumps used for irrigation and domestic supply (typically $<7.5 \mathrm{~m} / 25$ feet). The shallow aquifers across the Bengal Basin (i.e. $<$ $150 \mathrm{~m}$ depth) are fully recharged each year by monsoonal rain, with the water table rising above ground level in many areas during the monsoon to cause local inundation of lower ground with rainwater.

The present Bengal Basin comprises numerous major and minor river channels and the extensive interfluves that lie between them. A similar landscape would have existed around $125 \mathrm{ka}$, when sea level was around the level that it is today. In the interval $125 \mathrm{ka}$ to the last glacial maximum at $18 \mathrm{ka}$ (LGM), sea level fell by $120 \mathrm{~m}$. In that period, weathering and erosion developed a late Pleistocene landscape at an elevation mostly lower than that of today composed of interfluves and river valleys (Umitsu 1993; DPHE 1999; Goodbred and Kuehl 1999, 2000), the most prominent of which remain today as the Barind and Madhupur Tracts. Long weathering of the palaeo-interfluves formed on them a capping laterite of red clay (Goodbred and Kuehl 1999, 2000; termed here the last glacial maximum palaeosol, or LGMP) over weathered and oxidised sands that are now commonly termed 'brown sands' (DPHE 1999 et seq.) and represent part of the 'oxidised facies' of Goodbred and Kuehl (2000).

The rise of sea level after the termination of the LGM created the accommodation space for the accumulation of newer sediment on top of the late Pleistocene landscape. First, the pre-LGM palaeo-channels, incised to a maximum depth of $120 \mathrm{~m}$, were filled with mostly grey sands. Later sediments consisted of post-LGM floodplain silts, peats, and clays, incised by numerous later channel-fills of grey sands deposited as a result of channel avulsion. The channel-fills range in formational age from immediate post-LGM, in the base of main distributary channels, to modern deposits arising from modern river avulsion (DPHE 1999; Goodbred and Kuehl 1999, 2000; chapter 3, Ravenscroft 2003).

Within this sedimentological context, four sedimentological settings are recognised here (Fig. 1b) which have general meaning for As pollution. The channels present at 

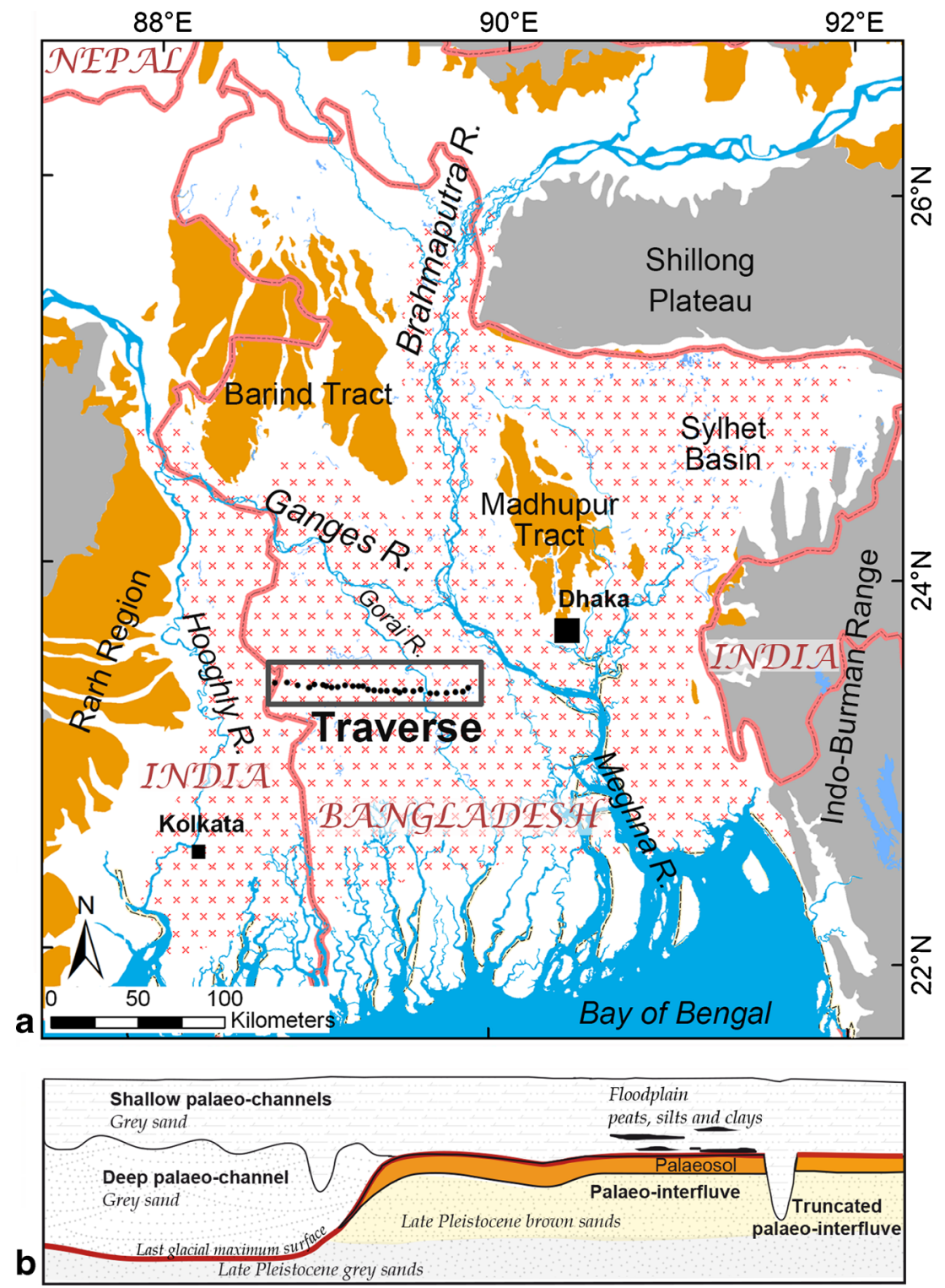

Fig. 1 a Map of Bengal Basin, showing regions most affected by As-polluted groundwater (red cross-hatch). Boxed is the traverse of 28 boreholes drilled to reveal subsurface sedimentology. Around each borehole, field analysis for As in water wells, and well-colour surveys (see section 'Methods' for details) confirmed the sedimentology revealed by drilling. Areas of solid dark brown show major outcrops of Pleistocene and older sediments (Madhupur Tract, Barind Tract, Rarh Region), the subsurface extensions of which this work sought to document. b A generalised illustration of aquifer settings (not to scale), showing four aquifer settings described in the text: palaeo-interfluve, truncated palaeo-interfluve, deep palaeo-channel, shallow palaeo-channel

the LGM, and infilled with grey sand as sea level rose, are termed here deep palaeo-channels (DPC). Shallow palaeochannels (SPC), typically $<30 \mathrm{mbgl}$, contain grey sands which were formed by avulsion of Holocene rivers after most of the basin-fill had been deposited. Where the LGMP directly caps late Pleistocene brown sands and underlying Pleistocene grey sands, the term PI setting is used. The term truncated palaeo-interfluvial sequences (TPI) is used for the setting where shallow palaeochannels have incised through the LGMP, depositing grey Holocene-to-modern sands directly onto brown, late Pleistocene sands.

The SPC aquifers are commonly exploited for water supply because they are the first aquifers to be Hydrogeology Journal (2014) 22: 1535-1547 encountered during drilling, usually at depths $<30 \mathrm{mbgl}$. The grey sands of the SPC and DPC aquifers usually contain As-polluted groundwater because reduction of sedimentary iron oxyhydroxides, that sorb As, in the aquifer sediments has commonly gone to completion and released that As to groundwater (Gulens et al. 1979; Nickson et al. 1998; Welch et al. 2000; McArthur et al. 2004). Groundwaters in PI aquifers typically have concentrations of As that are $<5 \mu \mathrm{g} / \mathrm{L}$ and commonly $<1 \mu \mathrm{g} / \mathrm{L}$ because the environment is poised at the redox state of Mn-reduction, rather than the As-polluting stage of Fe-reduction (McArthur et al. 2011).

Brown PI sands and grey PC sands are in contact in TPI sequences and at the margins of palaeo-channels. In 
both environments, As-polluted groundwater in the PC sands can invade the brown sands of the PI aquifers. The brown sands have a higher $\mathrm{Fe}(\mathrm{III}) / \mathrm{Fe}(\mathrm{II})$ than grey sands (Horneman et al. 2004) because the brown sands contain more sedimentary iron oxyhydroxide. That iron oxyhydroxide strongly sorbs As (e.g. Stollenwerk et al. 2007). At such contacts, the concentrations of As in PI groundwaters are locally $>5 \mu \mathrm{g} / \mathrm{L}$ because the sorption capacity of the brown sands is overwhelmed by As in the invading groundwater (McArthur et al. 2010).

\section{Methods}

To map the distribution of PI aquifers across Bangladesh, two methods were used. Firstly, the PI distribution was established using 1,580 rotary-drill logs made available by the DPHE, Government of Bangladesh DPHE/DFID/JICA (2006). Secondly, As, Fe, and Mn concentration of 2,387 well waters from the National Survey of Arsenic Contamination (DPHE 1999, 2001) were used as proxies for PI and PC settings (see the following section 'Regional water composition'). All locations are reported here in the WGS 84 co-ordinate system.

The distribution of PI aquifers predicted by these methods were then tested by site investigation at 28 locations along an east-west traverse across $115 \mathrm{~km}$ of Bangladesh (Fig. 1). At each site, a borehole up to 91 mbgl was drilled to reveal subsurface sedimentology but without installing a well. Also, from existing domestic wells located around each drill site, groundwater samples were collected for chemical analysis of PI/PC proxies. Finally, for a few hundred metres around each site, the colour of stain on further wellcompletions and on domestic utensils was documented. This was done because such colour can distinguish between PI and PC settings of the well (McArthur et al. 2011) and help locate the boundary between PI and PC settings to an accuracy of a few metres (McArthur et al. 2011; Hoque et al. 2012).

\section{DPHE rotary drilling logs}

Using 1,580 rotary borehole logs from known locations that were drilled to depths of at least $100 \mathrm{mbgl}$, a setting that was either PI or PC was assigned to each log on the basis of the similarity of the recorded lithology to type examples of PI and PC sequences from existing lithological records (Fig. 2; McArthur et al. 2004, 2008, 2011; Hoque et al. 2012). Core descriptions of others were also classified as PI or PC (BADC/MMI/HTS 1992; Davies and Exley 1992; Umitsu 1993; Goodbred and Kuehl 1999, 2000; Pal et al. 2002; van Geen et al. 2003b, 2007; von Brömssen et al. 2007; Pal and Mukherjee 2009; Burgess et al. 2010; Hoque et al. 2011; Pate et al. 2009), as few had recognised this distinction.

In none of the 1,580 DPHE logs was the distinction between PI and PC sequences recognised previously. It is the re-interpretation of these logs presented here that has allowed this distinction to be made. The key indicator of a PC sequence is the presence of sand at all depths, usually capped by surficial silt and/or clay typically only a few metres thick. The indicator of a PI sequence in the DPHE $\operatorname{logs}$ is the presence, at depths ranging from 26 to $34 \mathrm{mbgl}$ depending on location, of a unit of clay+silt which, where present, was taken to be the LGMP. This is the depth range at which it has either been recognised and reported as such, or reported but not recognised as the LGMP and so re-interpreted here as such (see preceding citations). Further necessary conditions for recognition of the LGMP was a thickness $>80 \mathrm{~cm}$ and that it was underlain by sands to the maximum depth examined. Where the LGMP was overlain by shallow palaeo-channel sands, identification of the clay between 26 and $34 \mathrm{mbgl}$ as the LGMP is unequivocal as it was the only fine-grained unit reported. Where the putative LGMP is overlain by a sequence of floodplain clays, silts, and peats, the presence of the LGMP was inferred because all such sequences so far drilled by the authors have the LGMP at the base of the clay sequence, under which was a thick sand (McArthur et al. 2001, 2004, 2008; Pal et al. 2002).

The process of assignment was assisted by converting $\operatorname{logs}$ to a digital format and processing them using an algorithm that measured the proportions of sand, and silt + clay, present in successive 2 m-thick segments of core. The output of grain-size with depth was diagnostic of either a PI or a PC sequence. The number of $\operatorname{logs}$ that satisfy the algorithm was sensitive to the thickness set for that depth slice. That sensitivity analysis suggests that the results must be taken as reporting a minimum number of locations at which a PI sequence may be present. The analysis further under-reports the frequency of PI sequences because the DPHE drilling logs did not record sediment colour. The algorithm therefore classified as PC sequences all TPI sequences, in which grey sands directly overlie brown sands with no intervening LGMP, e.g. the sequences at piezometer site AP in the village of Moyna, West Bengal (McArthur et al. 2004).

A further bias towards under-reporting of the PI sequence occurs because rotary drilling seldom allows recognition of clay/silt units that are thinner than about $3 \mathrm{~m}$ in thickness, so the absence of such a unit from a rotary drill log does not indicate with certainty the absence of the LGMP. Despite these caveats, the analysis outlined in the preceding is useful in allowing quantification of the minimum extent of the PI sequences present at modest depth in the Bengal Basin.

\section{Regional water composition}

The hydrochemical search for PI aquifers examined water compositions from 2,387 of the 3,234 published analyses of groundwater available from the National Survey off Arsenic Contamination, of Bangladesh conducted in 1997/ 1998 (DPHE 1999, 2001). Following McArthur et al. (2011, 2012) and Hoque et al. (2012), concentrations of $\mathrm{As}, \mathrm{Fe}$ and $\mathrm{Mn}$ in groundwater were used to differentiate between wells tapping PI sequences and those tapping PC 


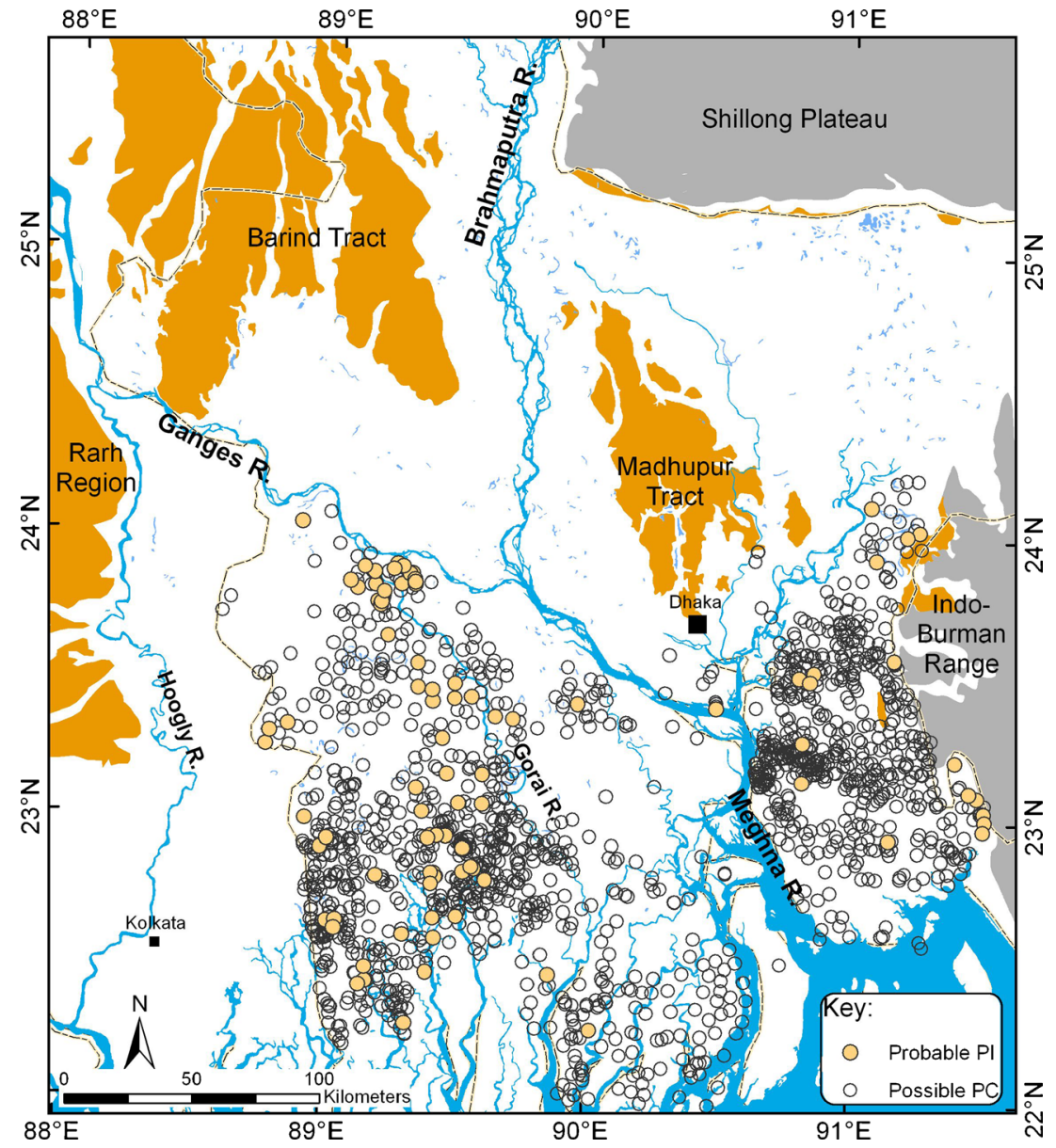

Fig. 2 Locations and classification of 1,580 lithological records used in this study. Sequence categorization is described in the 'Methods' section; for reasons given in the text, the proportion of PI settings is underestimated. Lithological logs were supplied by the Department of Public Health Engineering, DPHE, Government of Bangladesh. Open circles are locations where lithological logs suggest the presence of PC settings; filled circles are locations where lithological logs suggest the presence of PI settings. Areas of dark brown as in Fig. 1

sequences: PI groundwaters typically contain Mn, but no As or Fe; PC groundwaters typically contain As and Fe, but no Mn. Specifically, for wells between 20 and $90 \mathrm{~m}$ deep, the criteria set to identify PI groundwaters were: $\mathrm{Mn} \geq 0.2 \mathrm{mg} / \mathrm{L}$ and $\mathrm{Fe} \leq 0.9 \mathrm{mg} / \mathrm{L}$ and $\mathrm{As} \leq 10 \mu \mathrm{g} / \mathrm{L}$. For recognition of $\mathrm{PC}$ groundwater, criteria were: $\mathrm{Mn} \leq$ $0.2 \mathrm{mg} / \mathrm{L}$ and $\mathrm{Fe} \geq 0.9 \mathrm{mg} / \mathrm{L}$ and $\mathrm{As} \geq 10 \mu \mathrm{g} / \mathrm{L}$.

Excluded from consideration were wells screened at depths $>90$ or $<20 \mathrm{~m}$. Brown sands in the Bengal Basin have rarely been reported from depths $>90 \mathrm{~m}$, so wells screened below that depth are of limited usefulness in the search for PI brown sands. The shallow cut-off of $\leq 20 \mathrm{~m}$ depth is chosen because such wells must be screened in PC aquifers, as the minimum depth at which the PI brown sands have been found in the basin proper is around 25 mbgl. The top of the PI sequence trends to shallower depths as it approaches outcrop around the basin margin, and where it is close to the Barind and Madhupur Tracts, so the upper depth limit breaks down in such settings. Nevertheless, such settings form an insignificant part of the region studied and any anomalies they produce are unlikely to have a noticeable effect on the results or conclusions.

Hydrogeology Journal (2014) 22: 1535-1547

\section{Site investigation}

\section{Drilling}

The extent of the PI sequences predicted by the two aforementioned methods were tested by drilling 28 boreholes up to 300 foot $(91 \mathrm{~m})$ depth along a $115 \mathrm{~km}$ traverse running from west to east across half of Bangladesh from its western border (Fig. 1). The traverse crossed much of the As-polluted part of Bangladesh. The boreholes were variably spaced about 3-6 km apart. The local hand-operated reverse-circulation method (Ali 2003) was used for drilling with plastic pipe, which can drill to 300 feet $(91 \mathrm{~m})$ rather than the 200 feet $(61 \mathrm{~m})$ attainable with iron pipe used in West Bengal. Water wells were not installed in the boreholes. Rather, at each borehole, cuttings were continuously collected and monitored, and were logged every 5 feet $(1.52 \mathrm{~m})$ or where a distinct lithological change occurred (see the electronic supplementary material (ESM), in which it should be noted that each 5 foot interval on the photographic logs gives an example only of the sediment(s) recovered in that 5 foot interval). The hand-operated method faithfully recovers clay units (see figure S2, ESM), and can distinguish fine 
sand from course sands, and both from silts. Comparison of the hand-operated method with percussion coring at the same site (J.M. McArthur, University College London, unpublished data, 2012) had shown that, at all depths, the lithological records were comparable, although sharp lithological contacts in sands, e.g. between brown and grey sands that occur over millimetres in sediment cores, are smeared over a few feet in hand-operated holes.

\section{Water composition}

To test the match between sedimentology revealed by drilling, and that determined from groundwater composition, 176 unfiltered samples of well water were collected for laboratory analysis (see table S1, ESM) from domestic wells along the traverse, all but two screened at depth $\leq 90 \mathrm{mbgl}$. The wells were sited within a few hundred metres of the drill sites. Samples were not filtered because it has been shown that the As concentration of unfiltered and filtered waters are indistinguishable (Swartz et al. 2004; Zheng et al. 2005) and the major cation composition of filtered and unfiltered well waters have also proven indistinguishable unless the water is visibly turbid (J.M. McArthur, University College London, unpublished data, 2004); none of the samples were turbid. Samples analysed for $\mathrm{U}, \mathrm{V}, \mathrm{Mo}, \mathrm{Mn}, \mathrm{Fe}$, and As were acidified in the field with $0.15 \mathrm{ml}$ of $50 \%$ AnalaR nitric acid. Analysis for $\mathrm{Fe}$ and $\mathrm{Mn}$ was by ICP-AES; analyses for As, Mo, U, and V, were done using a Bruker 90 ICP-MS.

A further 129 wells (see table S2, ESM) were tested in the field for concentrations of As using a digital Arsenator, because in wells between 20 and $90 \mathrm{~m}$ deep, the absence of As typically indicates that the well taps a PI sequence. At another 74 sites (see table S3, ESM), distributed mostly between drill sites, this field analysis was augmented by noting the colour of stain left by well water on wellcompletions and domestic utensils. This use of colour follows the demonstration (McArthur et al. 2011) that red stain is typical of wells $<150 \mathrm{~m}$ deep that tap As-polluted PC groundwaters, whilst black stain is typical of wells that tap low-As groundwater from PI aquifers.

\section{Results}

\section{DPHE rotary drilling logs}

The DPHE lithological logs that were categorised as PI or PC sequence are plotted on a map of the study area shown in Fig. 2. It is re-emphasised that the number of logs interpreted as representing a PI sequence is underestimated by the analysis of these DPHE logs presented here, so the distribution shown should be viewed as representing the minimum number of such sites.

\section{Regional water composition}

The classification of 2,387 groundwater compositions into PC and PI settings are shown in Fig. 3. The putative occurrence of PI aquifers, shown as brown triangles, bears some correspondence to the region of As-free aquifers at depth predicted in figure 6 of McArthur et al. (2011). Note particularly the high density of wells that scatter SSE from the Barind Tract and reflect the presence of PI sequences at depth.

In Fig. 4 the sites of 'probable PI' based on water composition (Fig. 3) are lumped together with those based on lithological logs or drilling (Fig. 2) plus locations of brown sand reported in the literature. The figure shows (in light brown colouration) the predicted areas under which a PI sequence is probably present at depth in the Bengal Basin.

\section{Site investigation}

\section{Drilling}

The lithological logs obtained along the drilling traverse are compiled in Fig. 5. Examples of the sediments recovered and used to compile the logs are shown in the ESM. At 12 sites $(5,7,9,11-14,17,18,20,23,24)$, a full PI sequence was found comprising a palaeosol of red-clay, the LGMP, capping brown aquifer sands. At sites 18 and 20 , the PI sequence is overlain by fine, floodplain silts and clays; elsewhere, it is overlain by shallow PC sands. At a further four sites $(8,15,19,22)$, the PI and PC sands are separated by a pale-blue clay $1.5-3 \mathrm{~m}$ thick, rather than the LGMP, as has been noted to occur elsewhere (Hoque et al. 2012). The pale-blue clay was, in turn, overlain by organic-rich clay of $<1 \mathrm{~m}$ thick. At a further three sites $(6,10,21)$, a truncated PI sequence was found in which post-LGM channel erosion had cut through the palaeosol and overlying strata, but had not eroded much of the brown-sand sequence beneath, leaving grey, As-polluted, PC sands directly on brown PI sands, as has been found elsewhere (McArthur et al. 2011; Hoque et al. 2012).

The depth to the top of the LGMP ranged between 29 and $37 \mathrm{mbgl}$ and the thickness of the LGMP ranged from 0.5 to $5 \mathrm{~m}$. The brown sands beneath the LGMP yielded groundwater containing $<0.4 \mu \mathrm{g} / \mathrm{L}$ (median value, $n=77$ ) of As. The minimum depth to the top of the brown sand was $29 \mathrm{mbgl}$ and the thickness of the brown sands ranged from 4.6 to $>55 \mathrm{~m}$. Brown sand extended to the maximum depth drilled $(91.4 \mathrm{~m})$ at sites 22,23 , and 24. In other sites where brown sand was found, it passed downward into grey sand at depths between 55 and $86 \mathrm{mbgl}$. This basal colour transition marks the maximum depth of late Pleistocene weathering, and so approximate palaeo-base level, in past times (Hoque et al. 2012). These depths have not been corrected for subsidence that has occurred since deposition because local subsidence rates are unknown.

At nine sites $(1-4,16,25-28)$, grey PC sands were found extending to the full depth drilled. At the ends of the traverse (sites 1-4 and 25-28), the grey sands infill deep and wide pre-LGM palaeo-channels. At site 16, grey sands to the depth drilled infill a channel of width $3-5 \mathrm{~km}$ that probably was a distributary river at the time of the LGM. This site may document an early equivalent of the modern-day Gorai River, which is located nearby (Fig. 1). 


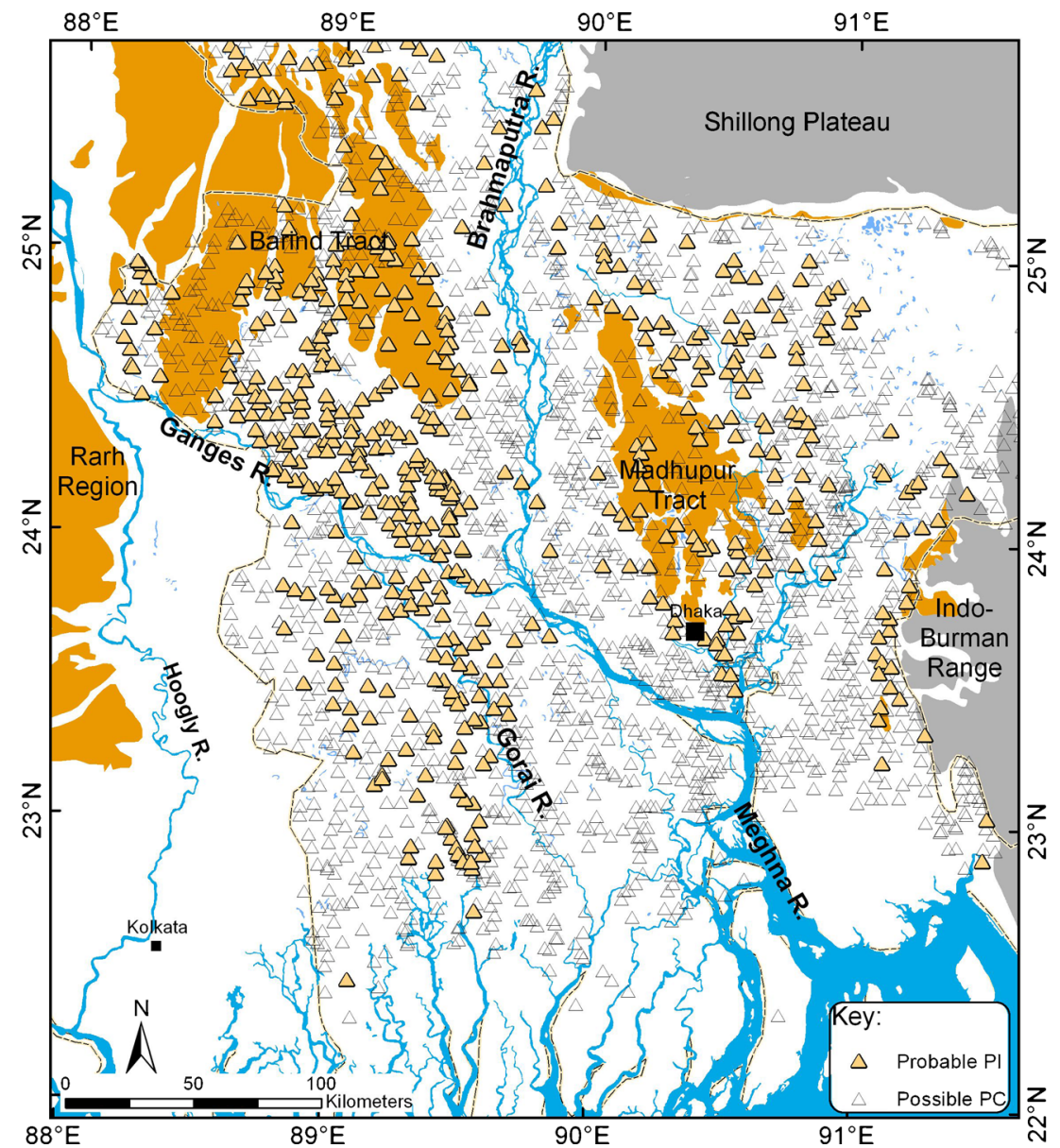

Fig. 3 Locations and classification of the composition of 2,387 well waters of DPHE used in this study. Classification was based on concentrations of Fe, Mn and As in groundwater (see section 'Methods'). Data from DPHE (1999), (2001). Open symbols represent locations where the composition of well water suggests a PC setting; filled symbols represent locations where the composition of well water suggests a PI setting. Areas of dark brown as in Fig. 1. Note that only wells in Bangladesh were reported in DPHE (1999, 2001)

The shallow PC sands overlying the buried PI sequences typically host As-polluted groundwater (McArthur et al. 2004), but of 14 samples collected in such shallow settings along the line of traverse, concentrations of As exceeded $57 \mu \mathrm{g} / \mathrm{L}$ in one outlier only of $384 \mu \mathrm{g} / \mathrm{L}$. Within the main PI tract, two narrow palaeo-channels occur.

\section{Water composition}

The results of well waters collected along the line of traverse are given (see table S1, ESM). Cross plots of element concentrations, given in Fig. 6, highlight the mutual exclusion of elements in PI and PC groundwater and lend confidence to the use of these element concentrations to separate PI and PC sequences on the grounds of groundwater composition. Along the line of traverse, profiles of $\mathrm{As}, \mathrm{Fe} / \mathrm{Mn}, \mathrm{V}$, and $\mathrm{U}$ (Fig. 7) delineate the regions of $\mathrm{PI}$ and $\mathrm{PC}$ aquifer.

Using colour to explore the subsurface lithology around drill sites and along the line of traverse between the drill sites, it was found that $94 \%$ of black wells $(n=79)$ confirmed the sedimentological setting for sites that had been deduced from drilling and water chemistry, and $81 \%$ of black wells contained $<10 \mu \mathrm{g} /$ L of As (see table S1, ESM). The difference represents wells at the margins of palaeo-interfluves where local migration of As-polluted waters has brought As to marginal PI settings and is now polluting wells that previously were low in As, as has been documented elsewhere (McArthur et al. 2010).

The combined colour and chemical data allowed mapping in detail of the contact between the regions of palaeo-interfluve and palaeo-channel, which can be identified in the field to within a few metres by such means (e.g. Hoque et al. 2012). Along the central, PI, part of the traverse, local areas of red-stained wells in which well waters contains $>10 \mu \mathrm{g} / \mathrm{L}$ of As (sites 8, $13,15,17,21)$, and low concentrations of $\mathrm{U}, \mathrm{V}$, and $\mathrm{Mn}$. The depth of these wells is within the range 30 $90 \mathrm{mbgl}$ at which PI brown sands would be found if they were present. The fact that PC signatures are seen locally in isolated small areas suggests they represent local incision of minor palaeo-channels through the LGMP, i.e. local scour to the depth of the brown sand. Such regions have proven to be uncommon in the mapping. 


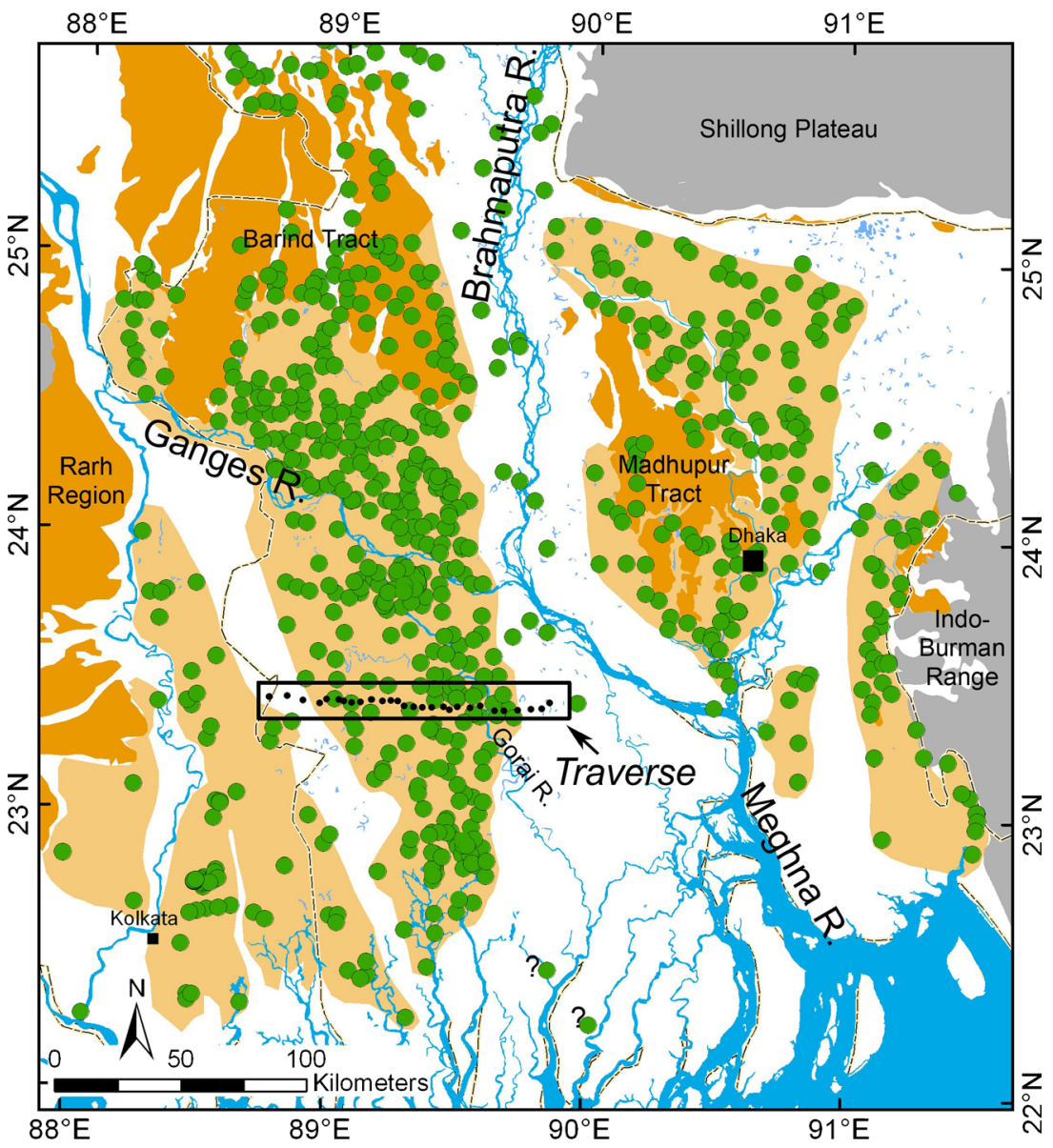

$$
\begin{array}{|cc|}
\hline \text { Key: - Probable PI } \text { - Drilling Sites } & \text { Probable PI Subcrop } \\
\text { PI Outcrop } & \text { Pre-Tertiary units }
\end{array}
$$

Fig. 4 Composite of Figs. 2 and 3, plus locations of brown sand reported in the literature. In this composite, sites of Probable PI based on water composition are lumped together with those based on historical logs and new drilling reported here. The figure shows in light brown colouration the predicted areas under which a PI sequence is probably present at depths between 20 and 90 mbgl in the Bengal Basin. The area covers around $45,000 \mathrm{~km}^{2}$ of the Bengal Basin. Areas of dark brown as in Fig. 1. The putative PI sequences should host groundwater containing $<5 \mu \mathrm{g} / \mathrm{L}$ As and typically much less. Note that palaeo-interfluves may be channelled locally at a scale too small to be visible here

\section{Discussion}

\section{Extent of low-As PI aquifers}

The analysis shows that low-As PI groundwaters that can be tapped from shallow depths accessible to local drilling methods are likely to be present under $45,000 \mathrm{~km}^{2}$ of the Bengal Basin, which is one third of its area (Fig. 4). These resources of low-As groundwater have not been much exploited by agencies responsible for potable-water supply. They have been overlooked by many owners of private wells who typically drill wells to the shallowest depth at which water may be obtained. That depth is often less than the depth to the local palaeo-interfluvial aquifer.

Along the line of traverse, the sediments revealed by drilling (Fig. 5) indicates that the middle portion of the traverse does indeed comprise a palaeo-interfluvial sequence, as predicted from water composition and DPHE logs. At both traverse ends, this central PI sequence is bounded by grey sands of As-polluted PC aquifers which occupy $40 \mathrm{~km}$ of the traverse. The post-LGM channels have not much truncated the PI sequence because their depth of incision has been mostly too shallow to do so, being imposed by decreased base-level gradients (Salter 1993) as sea level rose after $18 \mathrm{ka}$.

\section{Fragmentation of low-As PI aquifers}

The protection afforded by the LGMP, and the areal extent of PI aquifers, depends upon the degree of fragmentation of the late Pleistocene palaeo-interfluves. That fragmentation is governed by the initial distribution of rivers on that late Pleistocene landscape, and the degree to which subsequent channelling by post-LGM rivers has further fragmented those palaeo-interfluves. Such a large topic cannot be addressed fully here, but pointers exist that suggest such fragmentation is definitely not fractal in nature but instead has left many areas of PI aquifer that are tens of square kilometres in extent. 

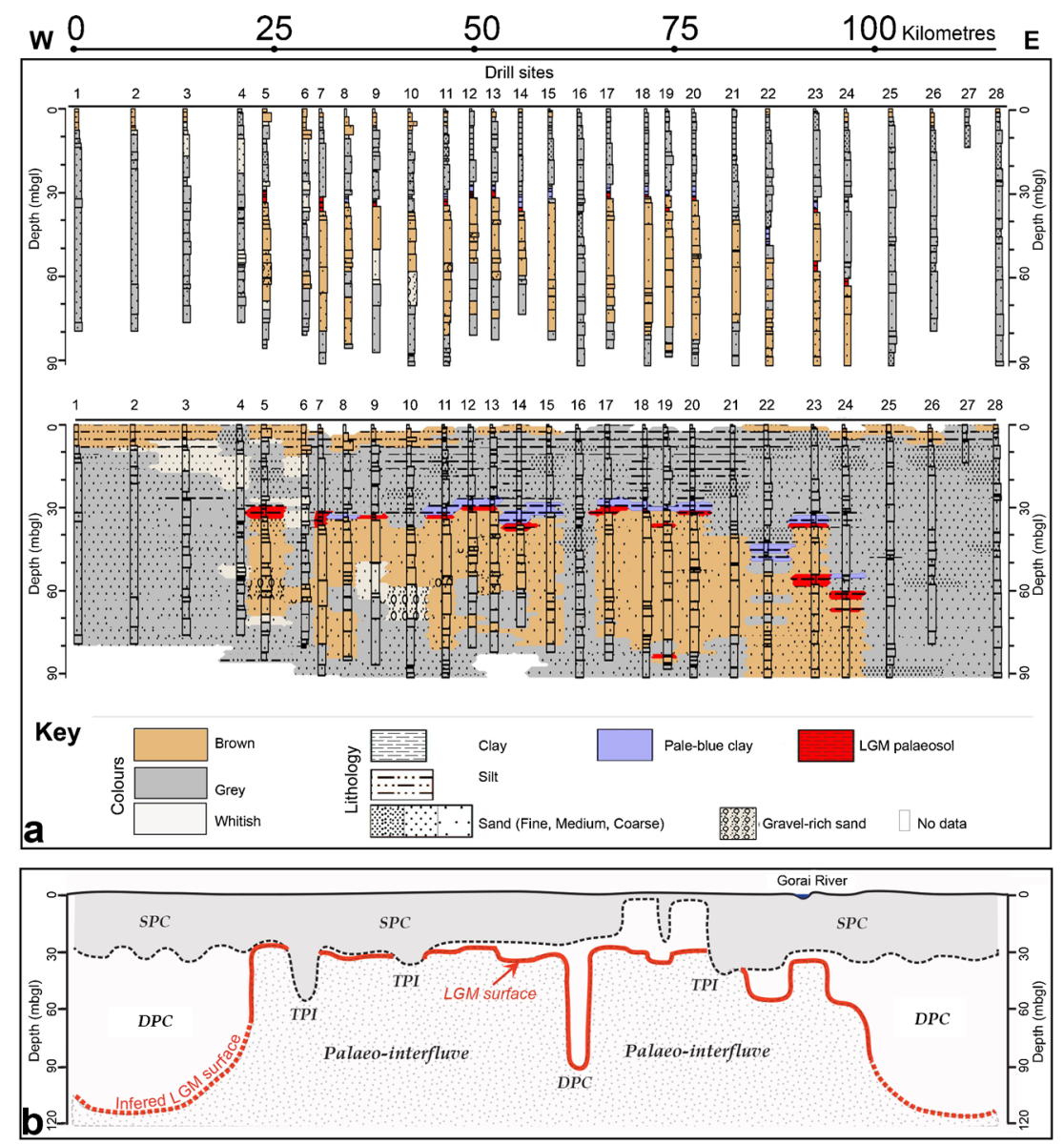

Fig. 5 Sedimentary sequences revealed by drilling along the traverse shown in Fig. 1. a Lithological records and geological section inferred from them. Note the variation in thickness of PI brown sand along the traverse. b Schematic topography of the land surface at the last glacial maximum (LGM) when sea level was some $120 \mathrm{~m}$ below that of today. SPC shallow palaeo-channel; $D P C$ deep palaeo-channel, TPI truncated palaeo-interfluve. Palaeo-channel and palaeo-interfluves were defined by drilling; the location of boundaries between them was refined using hydrochemistry and survey in the field of the colour of stain on water wells (see text). Note the presence of two palaeosols at sites 19, 23 and 24. The upper is interpreted to be the LGMP

Whilst boreholes provide point-verification of subsurface lithology, the subsurface lithology between such tiepoints can be reliably deduced from the composition of well water (McArthur et al. 2011; Hoque et al. 2012) and even from the colour of stain left by well water spilled on well completions (McArthur et al. 2011, 2012). Such investigations have shown that a borehole spacing of a few $\mathrm{km}(4-5 \mathrm{~km}$ in this study) reliably identifies major palaeo-channels. They have further shown that channelling at a finer scale has incised mostly to depths less than $30 \mathrm{~m}$ into the existing landscape, so preserving many of the buried PI sequences that mapped here. Where such incision has gone deeper, the fact is revealed by the presence of As-polluted wells that are screened at a depth greater than the depth to the local LGMP, which is typically at $25-30 \mathrm{~m}$.

It can be observed that post-LGM channelling does not often incise to a depth greater than $30 \mathrm{mbgl}$, which suggests that much potential exists for PI sequences to have avoided erosion (Hoque et al. 2012). Nevertheless, sites 6 and 16 show that channelling at a scale of $1 \mathrm{~km}$ can incise through the LGMP and so fragment the areas of PI; an important future task will be to delineate just how dissected the regions of buried PI aquifer are because the buried PI aquifers can be recharged only by lateral flow from adjacent palaeo-channels (McArthur et al. 2011, 2012). Data show that the spacing between such palaeochannels is between 6 and $10 \mathrm{~km}$.

It may be possible, in some areas, to delineate the PI and PC regions by examination of surface character using remotesensing images as has been shown elsewhere (Hoque et al. 2012); for example, along the line of traverse, PI regions have a surface expression that lacks visible channelling (Fig. 8a), whilst PC areas show such channelling (Fig. 8b).

\section{Protective nature of the LGMP}

The value in the Bengal Basin of brown sand aquifers as lowAs supplies of groundwater has been noted before (DPHE 1999; Pal et al. 2002; McArthur et al. 2004, 2008, 2011; Zheng et al. 2005; Stollenwerk et al. 2007; van Geen et al. 2007; von Brömssen et al. 2007; Pal and Mukherjee 2009; Burgess et al. 2010; Hoque et al. 2011, 2012). The local protection afforded to underlying aquifers in central Bangladesh by the residual 

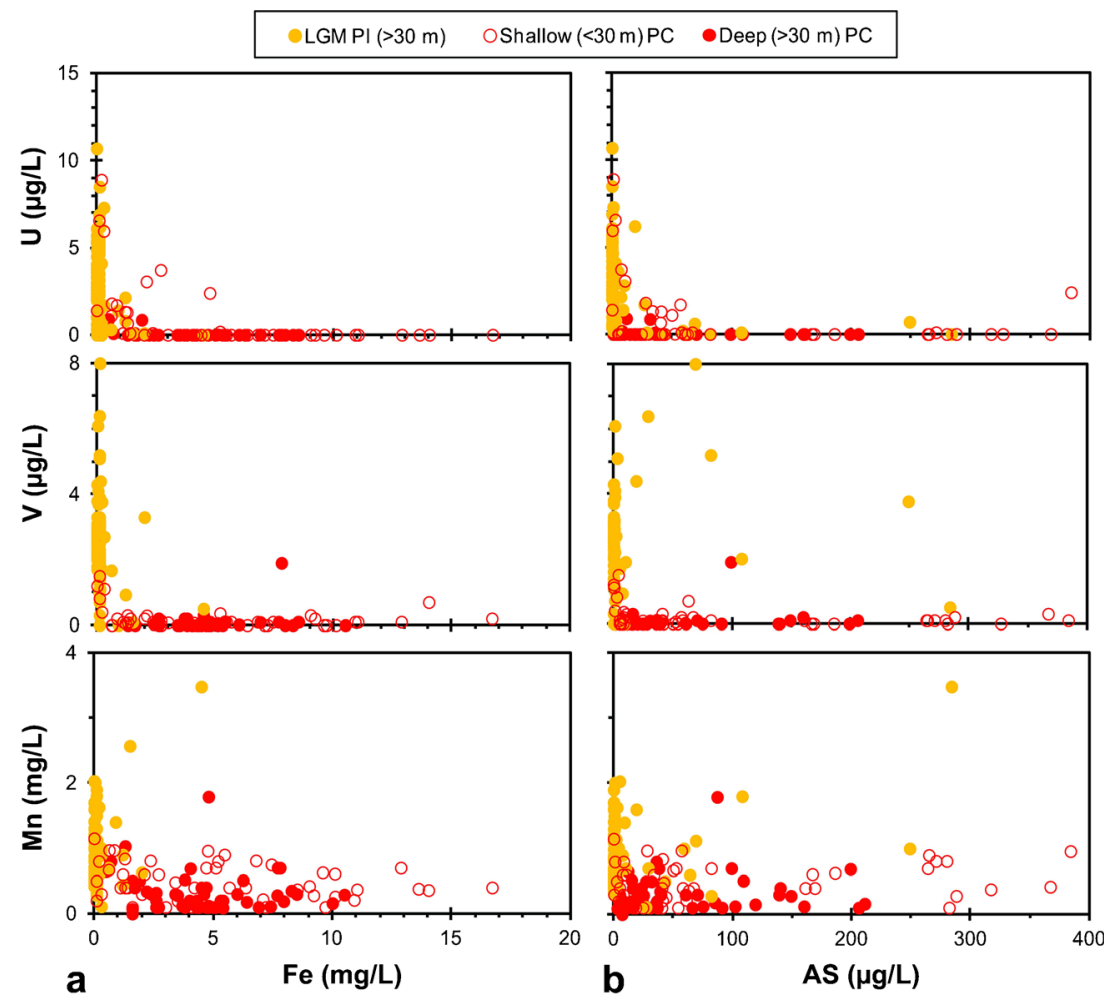

Fig. 6 Cross-plots of $A s, M n, F e, V$, and $U$ for groundwater from wells along the line of traverse shown in Fig. 1. The plots emphasize the mutual exclusivity of the element group Fe and As that characterise PC groundwaters, and the element group Mn, V, and U that characterize PI groundwaters

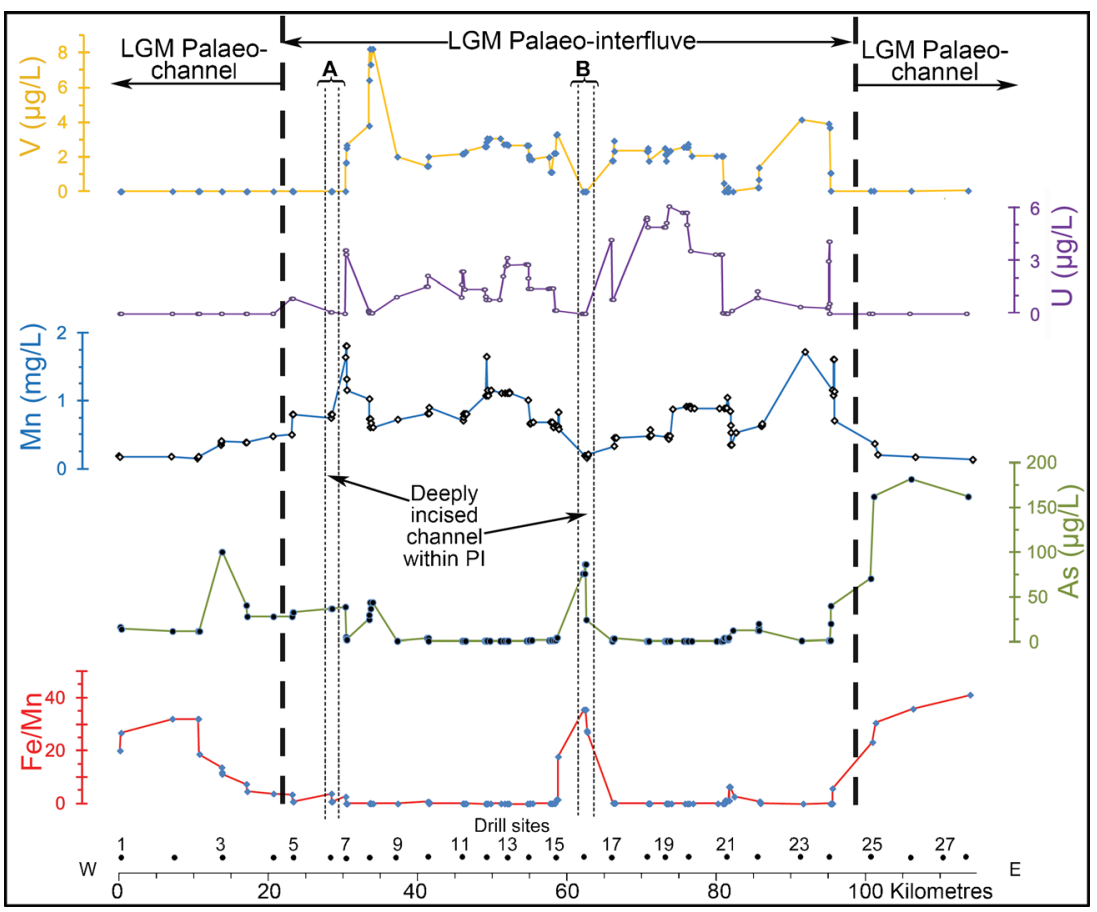

Fig. 7 Hydrochemical profiles along the traverse for wells between 20 and $91 \mathrm{~m}$ deep, shown as 5-point moving-medians. At the bottom, drill sites are numbered along the traverse. The PI areas are typified by low Fe/Mn ratios, low concentrations of As (mostly « $10 \mu \mathrm{g} / \mathrm{L}$ ), and concentrations of $U$ and $V$ in the low $\mu \mathrm{g} / \mathrm{L}$ range. In PC regions, groundwaters contain As $>10 \mu \mathrm{g} / \mathrm{L}$, little $\mathrm{Mn}$, no $\mathrm{U}$ or $\mathrm{V}$, and concentrations of $\mathrm{Fe}>0.9 \mathrm{mg} / \mathrm{L}$. Using these criteria, a central region of palaeo-interfluve can be defined that is flanked at the traverse ends by major palaeo-channels, and is interrupted at $A$ and $B$ by minor palaeo-channels.

Hydrogeology Journal (2014) 22: 1535-1547 

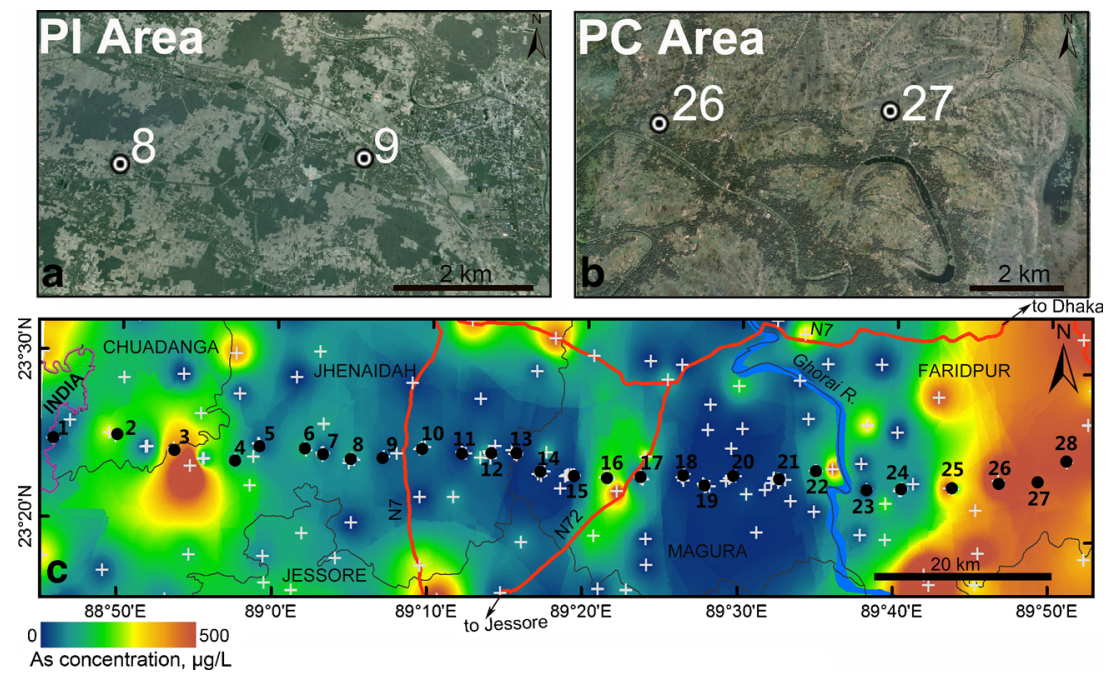

Fig. 8 a-b Satellite imagery (Google Earth Pro, with permission) showing surface features at a typical PI location (sites 8, 9) and at a typical PC location (sites 26, 27) on the traverse respectively. Regions of PI often lack surface channel-scars characteristic of PC regions. c Arsenic concentrations in groundwater along the traverse interpolated from the data (white crosses) of DPHE (1999, 2001) and this study (white crosses are covered by the black circles representing the drill sites). Drill sites numbered as 1-28. Roads are shown in red and boundaries of administrative units (districts) are shown in dark-grey

clays (palaeosols) of the Madhupur and Barind Tracts was recognised by Davies and Exley (1992) and Davies (1995). The more widespread role of the subcrop of the LGMP palaeosol in protecting aquifers across the Bengal Basin from As pollution was not, however, appreciated until relatively recently, following their documentation widely in the subsurface of West Bengal (McArthur et al. 2008, 2011; Hoque et al. 2012). The extent of the brown sand and capping palaeosol noted so far, however, represent but a minute fraction of the total area of the basin under which the data presented here suggests that such a sequence might lie.

This paper further confirms the palaeosol model of As pollution of groundwater (McArthur et al. 2008) which states that PI aquifers will be protected from downward migration of As in groundwater from overlying As-polluted aquifers by the impermeable LGMP. Thus, PI aquifers are likely to prove a long-term source of low-As groundwater.

\section{Mitigation}

The PI aquifers delineated in this study are suitable for mitigation of the As-pollution seen in PC aquifers. In many areas where the shallower SPC aquifers are currently exploited, they are underlain by PI aquifers, so mitigation would involve no more than drilling an existing well deeper so that its well-screen is emplaced in the brown sand of the underlying palaeo-interfluve, and so beneath the protective LGMP. Indeed, this is already the default position in areas where the palaeo-interfluvial sequence is overlain not by sands, but by clays, silts, and peats, through which wells must be drilled to reach the first sands (e.g. sites 18 and 20; others in McArthur et al. 2011).

At the boundary of the PI and PC settings, the composition of well water can give confusing signals of sedimentology because of changing water composition caused by lateral migration of As-polluted groundwater from PC aquifers into
PI aquifers in response to natural flow and pumping, especially pumping for irrigation. Changes can be marked over a period as little as 2 years (McArthur et al. 2010). LowAs wells become As-polluted and black well-stain becomes overprinted by red stain, making colour differentiation difficult. Wells in marginal PI settings a few metres to a few tens of metres downflow of such confusing well waters frequently have extremely high concentrations of $\mathrm{Mn}$ (typically $>2 \mathrm{mg} / \mathrm{L}$ ), which imparts to the well and the wellcompletion an intense black stain that is unmistakable in the field (McArthur et al. 2011). This is the best marker of the proximity to the boundary between palaeo-channel and palaeo-interfluve settings of wells, and allows boundaries to be mapped at the spatial scale of metres if wells are sufficiently common (Hoque et al. 2012; McArthur et al. 2012).

At PI margins, protection against lateral (horizontal) migration of As into PI aquifers is provided by sorption to sedimentary iron oxyhydroxide in the brown sands (Stollenwerk et al. 2007). Model estimates by that author for sorption coefficients $\left(K_{\mathrm{d}}\right)$ in Bangladesh sediments are around $30 \mathrm{~L} / \mathrm{kg}$. Measurements in Bangladesh at shallower levels $(\sim 6 \mathrm{mbgl})$, close to the zone of watertable fluctuation, indicate values of $7-8 \mathrm{~L} / \mathrm{kg}$ (Jung et al. 2012). Push-pull, in situ, experiments in Bangladesh gave a value of $13 \mathrm{~L} / \mathrm{kg}$ (Radloff et al. 2011). Assuming $K_{\mathrm{d}}$ value of $13 \mathrm{~L} / \mathrm{kg}$, a retardation factor 70 can be estimated for the brown sand of the Bengal Basin (taking $30 \%$ porosity, $1.6 \mathrm{~g} / \mathrm{cm}^{3}$ bulk density), and this value is in the range of field-based estimates of a factor of $>30$ by McArthur et al. (2010). Using this value in the OgataBanks solution (Ogata and Banks 1961), a well that is protected by a $50 \mathrm{~m}$ thickness of brown sand (e.g. one sited $50 \mathrm{~m}$ inside the margin of a PI sequence), would remain As free $(<10 \mu \mathrm{g} / \mathrm{L})$ for up to 525 years, assuming a groundwater velocity of $5 \mathrm{~m} /$ year, a hydrodynamic dispersion of $2 \mathrm{e}^{-7} \mathrm{~m}^{2} / \mathrm{s}$, and an As concentration in 
invading water of $100 \mu \mathrm{g} / \mathrm{L}$. These estimates are tentative, given the paucity of in-situ measurements of retardation factors for As and the degree of latitude on all and any of the governing parameters. It nevertheless allows an estimate to be made of the frequency with which wells in PI settings need to be tested, unless at the PI margins, and suggests a decadal timescale would suffice.

\section{The deep aquifer}

An increased use of deep aquifer water (from depths $>150 \mathrm{~m}$ ) is often invoked as an alternative source of water that can be substituted for the As-polluted water of the shallow aquifers. A major concern about this proposal is the possibility that increased abstraction from the deep aquifers of the Bengal Basin may draw down As from overlying aquifers. Because the brown sand of the PI sequences has the capacity to sorb As, it is often taken to be a barrier to the downward migration of As into the underlying deep aquifer (Stollenwerk et al. 2007; Radloff et al. 2011). Such invocations seldom recognise the limited thickness of the brown sand, which rarely exceeds $30 \mathrm{~m}$, and so far have never recognised that the LGMP will limit downward migration of water through brown sands and so reduce their effectiveness as a protective sorber.

Along the traverse, the pre-LGM brown sand is often thin ( $35 \%$ is $<20 \mathrm{~m}$ in thickness), and so has a limited capacity to delay downward migration of As, even were it to occur. Such downward flow from grey to underlying brown sand, however, cannot be widespread because brown sand is usually overlain by the LGMP and/or pale blue-grey clay (Fig. 5; McArthur et al. 2004; Hoque et al. 2012), the effective impermeability of which makes irrelevant, in most places, the sorptive capacity for As of the brown sand in respect of downward (vertical) migration of As. The sorptive capacity of brown sand may therefore be of little regional importance when assessing the vulnerability of the deeper aquifers to the downward breakthrough of As-rich groundwater from overlying aquifers in palaeo-channel settings.

Acknowledgements The work was supported by NERC grant NE/G/ 016879/1 to JMMcA and PKS. Charro and his drill team, and Talibun N. Molla, are thanked for assistance in the field, as are DPHE, and LGED, Bangladesh, for provision of data, and officials of the Government of Bangladesh for permission to stay in government guest-houses during the fieldwork. Roger Beckie and Martin Appold are thanked for their careful and constructive reviews.

\section{References}

Ahmed MF, Ahuja S, Alauddin M, Hug SJ, Lloyd JR, Pfaff A, Pichler T, Saltikov C, Stute M, van Geen A (2006) Ensuring safe drinking water in Bangladesh. Science 314:1687-1688
Ali M (2003) Groundwater resources and development in Bangladesh: background to the arsenic crisis, agricultural potential and the environment. In: Rahman AA, Ravenscroft P (eds) Bangladesh centre for advanced studies. University Press, Dhaka, Bangladesh

Argos M, Kalra T, Rathouz PJ, Chen Y, Pierce B, Parvez F, Islam T, Ahmed A, Rakibuz-Zaman M, Hasan R, Sarwar G, Slavkovich V, van Geen A, Graziano J, Ahsan H (2010) Arsenic exposure from drinking water, and all-cause and chronic-disease mortalities in Bangladesh (HEALS): a prospective cohort study. Lancet 376(9737):252-258

BADC/MMI/HTS (1992) Deep tubewell II project, esp. vol 2.1 natural resources. MMI and HTS for the Bangladesh Agricultural Development Corporation under the assignment to the Overseas Development Admin., Dhaka, Bangladesh

Burgess WG, Hoque MA, Michael HA, Voss CI, Breit GN, Ahmed KM (2010) Vulnerability of deep groundwater in the Bengal Aquifer System to contamination by arsenic. Nat Geosci $3(2): 83-87$

Davies J (1995) The hydrogeochemistry of alluvial aquifers in central Bangladesh, chap 1. In: Nash H, McCall GJH (eds) Groundwater quality. Chapman and Hall, London

Davies J, Exley C (1992) Short term BGS pilot project to assess the "Hydrochemical character of the main aquifer units of central and north-eastern Bangladesh and possible toxicity of groundwater to fish and human". Final report, Technical report WD/92/ 43R, British Geological Survey, Keyworth, UK

Dhar RK, Biswas BK, Samanta G, Mandal BK, Chakraborti D, Roy S, Jafar A, Islam A, Ara G, Kabir S, Khan AW, Ahmed SA, Hadi SA (1997) Groundwater arsenic calamity in Bangladesh. Curr Sci 73:48-59

DPHE (1999) Groundwater studies for arsenic contamination in Bangladesh, phase I: rapid investigation. Dept. of Public Health Eng., Bangladesh, British Geological Survey, Keyworth, UK

DPHE (2001) Arsenic contamination of groundwater in Bangladesh. In: Kinniburgh DG, Smedley PL (eds) Dept. of Public Health Eng., Bangladesh, British Geological Survey, Keyworth, UK, 267 pp. http://www.bgs.ac.uk/research/groundwater/health/ arsenic/Bangladesh/data.html. Accessed 20 June 2012

DPHE/DFID/JICA (2006) Development of deep aquifer database and preliminary deep aquifer map, Final report of first phase, Department of Public Health Engineering (DPHE), UK Department for International Development (DFID) and Japan International Cooperation Agency (JICA), Ground Water Circle, DPHE, Dhaka, Bangladesh pp. 165; http://dphe.gov.bd/aquifer/ index.php. Accessed 26 December 2010.

Fendorf S, Michael HA, van Geen A (2010) Spatial and temporal variations of groundwater arsenic in South and Southeast Asia. Science 328(5982):1123-1127

Goodbred SL Jr, Kuehl SA (1999) Holocene and modern sediment budgets for the Ganges-Brahmaputra River system: evidence for highstand dispersal to floodplain, shelf and deep-sea depocenters. Geology 27(6):559-562

Goodbred SL Jr, Kuehl SA (2000) The significance of large sediment supply, active tectonism, and eustasy on margin sequence development: Late Quaternary stratigraphy and evolution of the Ganges-Brahmaputra delta. Sediment Geol 133:227-248

Gulens J, Champ DR, Jackson RE (1979) Influence of redox environments on the mobility of arsenic in groundwater. In: Jenne EA (ed) Chemical modeling in aqueous systems, ACS Symposium Series 93:81-95, Washington, DC.

Hoque MA, Burgess WG, Shamsudduha M, Ahmed KM (2011) Delineating low-arsenic groundwater environments in the Bengal Aquifer System, Bangladesh. Appl Geochem 26(4):614-623

Hoque MA, McArthur JM, Sikdar PK (2012) The palaeosol model of arsenic pollution of groundwater tested along a $32 \mathrm{~km}$ traverse across West Bengal, India. Sci Total Environ 431:157-165

Horneman A, Van Geen A, Kent DV, Mathe PE, Zheng Y, Dhar RK, O'Connell S, Hoque MA, Aziz Z, Shamsudduha M, Seddiqu AA, Ahmed KA (2004) Decoupling of As and Fe 
release to Bangladesh groundwater under reducing conditions, part 1: evidence from sediment profiles. Geochim Cosmochim Acta 68:3459-3473

Jakariya M, Vahter M, Rahman M, Wahed MA, Hore SK, Bhattacharya P, Jacks G, Persson LÃ (2007) Screening of arsenic in tubewell water with field test kits: evaluation of the method from public health perspective. Sci Total Environ 379(2-3):167-175

Jung HB, Bostick BC, Zheng Y (2012) Field, experimental, and modeling study of arsenic partitioning across a redox transition in a Bangladesh aquifer. Environ Sci Technol 46(3):1388-1395

McArthur JM, Ravenscroft P, Safiullah S, Thirlwall MF (2001) Arsenic in groundwater: testing pollution mechanisms for sedimentary aquifers in Bangladesh. Water Resour Res 37(1):109-117

McArthur JM, Banerjee DM, Hudson-Edwards KA, Mishra R, Purohit R, Ravenscroft P, Cronin A, Howarth RJ, Chatterjee A, Talkdar T, Lowry D, Houghton S, Chadha DK (2004) Natural organic matter in sedimentary basins and its relation to arsenic in anoxic groundwater: the example of West Bengal and its worldwide implications. Appl Geochem 19:1255-1293

McArthur JM, Ravenscroft P, Banerjee DM, Milsom J, HudsonEdwards KA, Sengupta S, Bristow C, Sarkar A, Tonkin S, Purohit R (2008) How paleosols influence groundwater flow and arsenic pollution: a model from the Bengal Basin and its worldwide implication. Water Resour Res 44:W11411

McArthur JM, Banerjee DM, Sengupta S, Ravenscroft P, Klump S, Sarkar A, Disch B, Kipfer R (2010) Migration of As, and 3H/ $3 \mathrm{He}$ ages, in groundwater from West Bengal: implications for monitoring. Water Res 44(14):4171-4185

McArthur JM, Nath B, Banerjee DM, Purohit R, Grassineau N (2011) Palaeosol control on groundwater flow and pollutant distribution: the example of arsenic. Environ Sci Technol 45(4):1376-1383

McArthur JM, Sikdar PK, Nath B, Grassineau N, Marshall JD, Banerjee DM (2012) Sedimentological control on Mn, and other trace elements, in groundwater of the Bengal delta. Environ Sci Technol 46(1):669-676

Nickson R, McArthur JM, Burgess WG, Ahmed KM, Ravenscroft P, Rahman M (1998) Arsenic poisoning in Bangladesh groundwater. Nature 395:338

Nickson R, Sengupta C, Mitra P, Dave SN, Banerjee AK, Bhattacharya A, Basu S, Kakoti N, Moorthy NS, Wasuja M, Kumar M, Mishra DS, Ghosh A, Vaish DP, Srivastava AK, Tripathi RM, Singh SN, Prasad R, Bhattacharya S, Deverill P (2007) Current knowledge on the distribution of arsenic in groundwater in five states of India. J Environ Sci Health Part A 42(12):1707-1718

Ogata A, Banks RB (1961) A solution of the differential equation of longitudinal dispersion in porous media. US Geol Surv Prof Pap 411-A, 9 pp

Pal T, Mukherjee P (2009) Study of subsurface geology in locating arsenic-free groundwater in Bengal delta, West Bengal, India. Environ Geol 56(6):1211-1225

Pal T, Mukherjee PK, Sengupta S, Bhattacharyya AK, Shome S (2002) Arsenic pollution in groundwater of West Bengal, India: an insight into the problem by subsurface sediment analysis. Gondwana Res 5(2):501-512

Pate RD, Goodbred SL Jr, Khan SR (2009) Delta double-stack: juxtaposed Holocene and Pleistocene sequences from the Bengal Basin, Bangladesh. Sedimen Rec 7(3):4-9

PHED (1991) National drinking water mission project on arsenic pollution in groundwater in West Bengal. Final report, Steering
Committee, Arsenic Investigation Project, PHED, Govt. of West Bengal, Kolkata, India, $57 \mathrm{pp}$

Radloff KA, Zheng Y, Michael HA, Stute M, Bostick BC, Mihajlov I, Bounds M, Huq MR, Choudhury I, Rahman MW, Schlosser P, Ahmed KM, van Geen A (2011) Arsenic migration to deep groundwater in Bangladesh influenced by adsorption and water demand. Nat Geosci 4:793-798

Ravenscroft P (2003) Overview of the hydrogeology of Bangladesh. In: Rahman AA, Ravenscroft P (eds) Groundwater resources and development in Bangladesh: background to the arsenic crisis, agricultural potential, and the environment. The University Press, Dhaka, Bangladesh

Ravenscroft P, Brammer H, Richards KS (2009) Arsenic pollution: a global synthesis. Wiley-Blackwell, London

Salter T (1993) Fluvial scour and incision: models for their influence on the development of realistic reservoir geometries. Geol Soc Lond Spec Publ 73(1):33-51

Sengupta S, Sarkar A (2006) Stable isotope evidence of dual (Arabian Sea and Bay of Bengal) vapour sources in monsoonal precipitation over north India. Earth Planet Sci Lett 250:511-521

Smith AH, Lingas EO, Rahman M (2000) Contamination of drinking water by arsenic in Bangladesh: a public health emergency. Bull World Health Org 78(9):1093-1103

Stollenwerk KG, Breit GN, Welch AH, Yount JC, Whitney JW, Foster AL, Uddin MN, Majumder RK, Ahmed N (2007) Arsenic attenuation by oxidized aquifer sediments in Bangladesh. Sci Total Environ 379(2-3):133-150

Swartz CH, Blute NK, Badruzzman B, Ali A, Brabander D, Jay J, Besancon J, Islam S, Hemond HF, Harvey CF (2004) Mobility of arsenic in a Bangladesh aquifer: inferences from geochemical profiles, leaching data, and mineralogical characterization. Geochim Cosmochim Acta 68(22):45394557

Umitsu M (1993) Late Quaternary sedimentary environments and landforms in the Ganges Delta. Sediment Geol 83:177-186

van Geen A, Ahmed KM, Seddique AA, Shamsudduha M (2003a) Community wells to mitigate the current arsenic crisis in Bangladesh. Bull World Health Org 81:632-638

van Geen A, Zheng Y, Versteeg R, Stute M, Horneman A, Dhar R, Steckler M, Gelman A, Small C, Ahsan H, Graziano J, Hussein I, Ahmed KM (2003b) Spatial variability of arsenic in 6000 tube wells in a $25 \mathrm{~km}^{2}$ area of Bangladesh. Water Resour Res 39(5):1140-1155

van Geen A, Cheng Z, Jia Q, Seddique AA, Rahman MW, Rahman MM, Ahmed KM (2007) Monitoring 51 community wells in Araihazar, Bangladesh, for up to 5 years: implications for arsenic mitigation. J Environ Sci Health A 42(12):1729-1740

von Brömssen M, Jakariya M, Bhattacharya P, Ahmed KM, Hasan MA, Sracek O, Jonsson L, Lundell L, Jacks G (2007) Targeting low-arsenic aquifers in Matlab Upazila, southeastern Bangladesh. Sci Total Environ 379:121-132

Welch AH, Westjohn DB, Helsel DR, Wanty RB (2000) Arsenic in groundwater of the United States: occurrence and geochemistry. Ground Water 38:589-604

Zheng Y, van Geen A, Stute M, Dhar RK, Mo Z, Cheng Z, Horneman A, Gavrieli I, Simpson HJ, Versteeg R, Steckler M, Grazioli-Venier A, Goodbred S, Shahnewaz M, Shamsudduha M, Hoque MA, Ahmed KM (2005) Geochemical and hydrogeological contrasts between shallow and deeper aquifers in the two villages of Araihazar, Bangladesh: implications for deeper aquifers as drinking water sources. Geochim Cosmochim Acta 69:5203-5218 